\title{
The concepts of strategy and business models in firm internationalization research: Towards a research agenda
}

\author{
Marian Gorynia, Piotr Trąpczyński, Szymon Bytniewski
}

\begin{abstract}
A B S T R A C T
Objective: To discuss concepts of strategy and business models and reflect upon their commonalities and mutual relationships. Discussion about usage of both concepts with regard to the international expansion decisions.

Research Design \& Methods: The article is based on the literature studies.

Findings: Some of the dimensions of both concepts, including the operating modes, choice of products or markets, are common to both concepts. However, internationalisation appears to be an integral part of corporate-level strategy which defines the directions of long-term firm development, including the geographic dimension. Thus, considering different geographic commitments as partly independent, one can assume that while the entire firm has a business model as a whole, there can also be varieties of business models within the same organisation, which are a consequence of its growth, particularly internationalisation.
\end{abstract}

Contribution \& Value Added: Internationalisation research can also contribute to the stream on business model innovation, as the internationalisation of a firm's operations can be regarded as an organisational innovation in itself. A business model innovation requires a firm to timely and effectively identify and anticipate relevant developments in its constantly changing environment. The initiative to innovate an established business model has been identified as highly challenging due to its complexity and a range of barriers, particularly widespread inertia.

\begin{tabular}{ll}
\hline Article type: & research paper \\
Keywords: & Strategy; business models; internationalization; international com- \\
& petitiveness; international business \\
JEL codes: & F2, F23
\end{tabular}
Article received: 7 January 2019 Article accepted: 11 June 2019

\section{Suggested citation:}

Gorynia, M., Trąpczyński, P., \& Bytniewski, S. (2019). The concepts of strategy and business models in firm internationalization research: Towards a research agenda. International Entrepreneurship Review (previously published as International Entrepreneurship / Przedsiębiorczość Międzynarodowa), 5(2), 7-21. https://doi.org/10.15678/IER.2019.0502.01 


\section{INTRODUCTION}

Firm internationalisation belongs to key research paradigms that occur within the international business discipline (apart from such paradigms as: international enterprise, foreign direct investments, international trade, location of foreign enterprises, etc.). If the paradigm should be understood as a set of the most important theoretical problems related to research concerning a given issue, then in the case of the internationalisation paradigm of an enterprise, two categories should definitely be included in the set: firm strategy and business model.

The concept of firm strategy is commonly understood as the intended action or action plan that the company intends to implement during its operation in order to increase its competitive advantage. The strategy, according to the definition proposed by Obłój (2002), is something that has a fundamental impact on the survival or failure of the firm. Strategy is also understood as a set of company behaviour in relation to dynamically changing conditions closer to the environment and further. Business strategies are characterised by high flexibility, which enables companies to quickly change the previously outlined action plan. The term of the firm strategy has been analysed and researched many times, making it difficult to choose one proper definition of a concept (Gorynia, 2007).

While the concept of business models has been applied to firm internationalisation recently (Hennart, 2014; Onetti, Zucchella, Jones, \& McDougall-Covin, 2012; Rask, 2014), it still remains in its infancy and the related contributions pertain to specific aspects in isolation. Hence, the objective of the paper is to determine the usefulness of the concept of firm strategy and business models to research on firm internationalisation, and to clarify the relationships between the concepts. The paper relies on a literature review, in which a broad review and evaluation of both analytical concepts has been carried out, allowing to generate directions for further research on firm internationalisation processes.

\section{LITERATURE REVIEW}

\section{Foundations of firm strategy and business models}

In management science, strategy is understood in many ways. Systematically emphasised features of understanding the concept are: defining missions, methods enabling its fulfilment, measurability, location of strategies in time and relations established with the external environment (Doligalski, 2014). Expanding the understanding of the concept, strategy in newer studies is considered as a plan or scheme that integrates fundamental tasks in the company, defines the directions of action and behaviour logic. The correct formulation of the strategy enables effective location of resources. A well-prepared strategy also helps to react to the activities of competitors (Gorynia, 2007). Hitt, Ireland and Hoskisson (1999) stress the importance of analysing the environment and examining the internal conditions of the company's operations.

Porter (2001) takes the view that strategy should lead to an increase in the competitiveness of the company and emphasize its uniqueness. According to Porter, this means deliberately choosing a unique set of actions to deliver a unique mix of value. Porter claims that the strategy consists of a competitive position, differentiating oneself in the eyes of the client and adding value through a combination of activities other than those enjoyed by 
competitors. At this point, it is crucial to refer to a common typology of strategies that distinguishes the firm strategy at three levels (Porter, 1980). Depending on the organisation in which the strategy is created and used, three levels can be distinguished. A corporate-level strategy is shaped by the top management and overlooks the activities of an organisation which deals with more than one type of business. It deals with actions taken by the organisation as a whole and aims at defining the role of each of the various activities. With a goal of optimising company operations, profitability and growth, corporate strategy must compare the return of a continuing investment in the single business with the acquisition or starting up of complementary businesses (Hitt, Ireland, \& Hoskinsson, 1999).

The second level of strategy is that of the Strategic Business Unit (SBU). The business strategy sets, goals, and results. The business strategy sets goals for performance, evaluates the actions of competitors and specifies actions the company must take to maintain and improve its competitive advantages. Typical strategies are to become a low-price leader, to achieve differentiation in quality or other desirable features or to focus on promotion.

Finally, strategy at the functional level creates a framework for managing such functions as finance, research and development, marketing, ecology, in accordance with the strategy of the operating unit (Mintzberg, Ahlstrand, \& Lampel, 1998). This strategy consists in determining how a given function is to be implemented in order to foster the desired competitive advantage and to coordinate a given function.

In strategy literature, some authors tend to present the firm as a value chain. This concept assumes that the firm is a system consisting of elements connected by a network. According to Timmers (1998), in the concept of business model extends the general value chain in that it defines the integration of its elements. Combining the concept of business architecture and the concept of the value chain formulated by Porter (2001), Timmers (1998) stated that business models are created by three components:

- The architecture of goods and services, including the description of all parties (actors) involved in the exchange of products;

- Vision of potential profit for business participants (both the demand and supply side);

- Description of revenue sources.

Obłój (2002) claims that by combining firm strategy and its implementation, it is possible to fully use resources and skills. According to this approach, it is possible to define business models by addressing the questions of what the business of the firm is, what resources and technologies should the company have at its disposal so that it is possible to gradually build a competitive advantage, and how a resource chain should be configured.

Afuah and Tucci (2003) take the position that business models implemented by enterprises have one common denominator, they were created to bring profit in the long run. Another attempt to explain the concept under consideration is the approach presented by Stähler (2002). In his concept, he emphasises that the business model is a simplified picture of the current situation in a given industry. It presents the concept of the model as a tool for interpreting the basic elements of the enterprise and allowing for planning any changes or modifications.

Stähler distinguished three elements that compose the creation of a business model:

- The value offered, that is how the value of the company has to offer potential buyers of goods; 
- Products (offers on the market), architecture (thanks to what resources and activities is created);

- The revenue model (how the company generates income).

Gołębiowski, Dudzik, Lewandowska, Witek-Hajduk (2008) describes the business model as a configuration of four elements. First, the value proposition for the client (material benefits, transaction cycle, relations with final consumers, benefit cost relation), secondly resources (equipment, capital, high-tech, brand) are listed, thirdly, the position in the supply chain ( activities related to sales, marketing and production, typology of existing links and role in the supply chain). As the fourth element Golębiowski, Dudzik, Lewandowska, Witek-Hajduk (2008) distinguished sources of revenues (manufactured goods, delivered services or commercial outsourcing).

According to Ostenwalder and Pigneur (2010), the business model is a collection of elements and relationships that enable presentation of the company's business goals. These authors have proposed that a well-designed business model should be carefully planned and include the following areas of the company's operations:

- customer segments (an enterprise serves one or more customer segments),

- value proposition (the organisation tries to satisfy the clients' needs through the value proposition),

- channels (value proposition reaches customers via distribution channels, communication and sales),

- customer relationship (there are specific clients with whom the company can establish relationships),

- revenue streams (revenue streams are determined by the effects of the value proposal implementation),

- key resources (they include assets that are necessary to form other elements of the model)

- key activities (key activities for the enterprise),

- key partners (some of the activities are outsourced to partners or external companies and some are obtained from outside the enterprise),

- cost structure (each of the elements of the business model affects the structure of costs).

Based on the above review of the business model literature, an attempt can be made to formulate the conclusion that most of them are connected with business activities aimed at enhancing financial performance, while building competitive advantage in a dynamic environment, as well as creating value propositions for customer. The common denominators of almost all of the business model concepts discussed here, accordingly, are three elements:

- Value proposition for the client;

- Structure of the value chain / company position in the value chain;

- Sources of income.

\section{Comparison of strategy and business model concepts}

Referring to the above terminological deliberations, it appears legitimate to compare and differentiate between business models and company strategies. Magretta (2002) in his definition of the business model emphasises that it is a set of concepts that condition the 
creation of values for all entities involved in relations with the enterprise. He also believes that the model is "a theory that is constantly verified by the market". Therefore, the business model is a theoretical attempt to present the enterprise environment, but its implementation must take place in a direct relationship and be consistent with the strategy that allows the implementation of activitiesIn summary, according to Magretta's theory, the strategy is a complement to the business model.

Ostenwalder and Pigneur (2010) compared the business model and strategy. According to the authors, "the business model describes the reasons behind the way in which the organisation creates value and ensures and profits from this generated value." In combination with relevant business practices, these constituents of the business model define the type of strategy by which the company will operate on the market.

Summing up the above discussion, both the concept of business strategies and the concept of a business model are key concepts in management sciences, but they are often understood differently. Doligalski (2014) is of the opinion that "the business model represents what the company is, while the strategy describes the goals and forms and ways to achieve them by the company". Differences between the two concepts are summarised in Table 1.

Table 1. Comparison of firm strategy and business model concepts

\begin{tabular}{|c|c|}
\hline Firm strategy & Business model \\
\hline $\begin{array}{c}\text { Answers the question: What is the purpose of } \\
\text { the company and how can it be achieved? }\end{array}$ & $\begin{array}{c}\text { It is a simplified image of the company and an- } \\
\text { swers the question: What is the company? }\end{array}$ \\
\hline $\begin{array}{c}\text { It is created in relation to other entities from the } \\
\text { company's environment }\end{array}$ & It concerns the interior of the enterprise \\
\hline $\begin{array}{c}\text { It refers to the positioning and competitive ad- } \\
\text { vantage achieved by the company }\end{array}$ & It focuses on the created economic value \\
\hline It is characterised by flow marks & He has signs of state \\
\hline $\begin{array}{c}\text { It applies to the time dimension and provides for } \\
\text { the direction of changes }\end{array}$ & It is the image of an organisation captured at a \\
given moment
\end{tabular}

Source: own study based on (Doligalski, 2014).

Analysing the approaches presented by the quoted researchers regarding the similarities and differences between the strategy and the business model, several conclusions can be made. When emerging the relationship between the two concepts, it is worth applying the similarity criterion.

Firm strategy and business model cover other areas of activity (Fig.1 situation A). Doligalski (2014) analysing the relationships between the two concepts, takes the position that strategy is different from the business model, however, he clearly stressed that some approaches to defining strategy as a concept may coincide with the term business model. He also takes the position that the strategy reflects the desired target state, while the business model describes the current way of operation.

The subordination of firm strategy to the business model (Fig.1 situation B). The second approach concerns the theory that assumes, as a consequence, that the strategy is part of the business model. Magretta (2002)presents a theory in which he emphasises that having a coherent business model does not guarantee the company's success. The business model, understood as a system, describes the components of the company's activities and their 
mutual relations. The guarantee of success is having a competition strategy that defines ways to overcome rivals within the sector. In summary, Magretta defined the strategy as a complement to the business model. Stähler (2002) emphasises in his concept that the business model is a simplified picture of the current situation in the given industry. It presents the concept of the model as a tool for interpreting the basic elements of the company and allowing for planning any changes or modifications. It also contains a strategy that is necessary in the process of striving to achieve a competitive advantage. According to the theory presented by Gołębiowski, Dudzik, Lewandowska, Witek-Hajduk (2008) the strategy is part of the model. The business model presents general assumptions according to which a company's competition strategy is created. A similar position was presented by Osterwalder, and Pigneur (2010). According to its theory, a business model can be understood as a conceptual relationship between strategy, business organisation and business systems.

A.
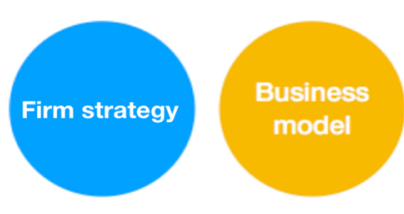

C.

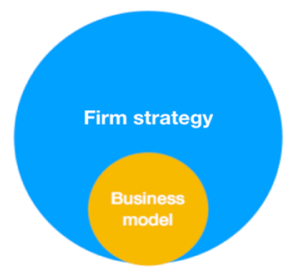

B.

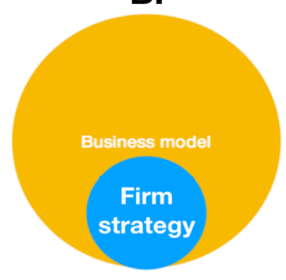

D.

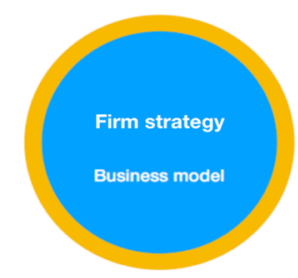

Figure 1. Relationships between the business model and the firm strategy Source: own elaboratio.

The company's strategy is superior to the business model (Fig.1 situation C). The third approach concerns theories that assume that the strategy is part of the business model. Obłój (2002) emphasises in his theory that if a business model assumes value creation, profit is not always equivalent to the assumed one. It also indicates the direct relationship between the strategy and its practical implementation, based on the concept of the value chain. He takes the position that the business model combines elements of strategy together and is part of it. Afuah and Tucci (2003), presented a theory in which emphasises the superiority of the strategy towards the business model of strategic units (SUB). He also claims that business models contain strategies relating directly to the SUB.

The concepts of the company's strategy and business model are interchangeable (Fig.1 situation D). Such an extreme position was presented by Porter (2001) who denied the value of the concept of the business model. His theory, widely regarded as misleading 
or omitted, because the concept of a business model would be unnecessary. Most researchers accuse him of misunderstanding the business model as a business model. Porter's approach is unique and the only one that rejects the existence of a business model.

Business model definitions are required that clearly identify and distinguish what is strategy, and what is the business model. Doligalski (2014) underlined that "a business model is not a strategy". Strategy and the business model intervene at various levels of the business decision process. Strategy belongs to an upper level, since it selects the business/businesses where to compete (corporate strategy) and defines how to position for each of them (business strategy). The business model logically is presented at operational level, since it defines how to execute the strategy, representing the firm's underlying core logic and strategic choices. Stähler (2002) expresses this point effectively: "emphasises in his concept that the business model is a simplified picture of the current situation in the given industry.", while Osterwalder and Pigneur (2010) define the business model as "the conceptual and architectural implementation of a business strategy". By excluding strategy from the defining elements of the business model and without using excessively general elements which are difficult to specify, the terms are more clearly explained. The conducted research provides the findings that the business model and business strategy are different, though somewhat similar objects of scientific exploration. Their combined use potentially allows better understanding of business operations and their performance.

\section{MATERIAL AND METHODS}

\section{Internationalisation strategy and its dimensions}

Welch and Luostarinen (1988) define internationalisation as "the process of increasing involvement in international operations"( p. 36). Given the organisational and environmental complexity, which increases with the extension of a firm's international activities (Verbeke, Li \& Goerzen, 2009), it seems legitimate to adopt a more holistic definition of internationalisation as firms adapt various aspects of their operations (strategy, structure, resources, etc.) to the international setting (Calof \& Beamish, 1995). Hence, internationalisation should not be regarded only from the perspective of entering new foreign markets, but more comprehensively - of devising a strategy for developing and managing international operations. And yet, the choice of foreign operation modes has remained the predominant object of analysis in IB literature (Calof \& Beamish, 1995; Fletcher, 2001). This seems understandable given that the initial mode choice is critical to establishing the basis for further foreign market penetration (Benito \& Welch, 1994; Welch \& Luostarinen, 1988). Since market entry modes are a determinant of resource commitment to a foreign market, they are a relevant strategy dimension in managing the international involvement.

However, the dimension of operating modes cannot fully reflect the internationalisation process, since a partial increase or withdrawal in terms of operating modes might not be indicative of the overall exposure to cross-border operations. A substitution of the changed operating mode through other modes or the transfer of resources to other countries can increase the international market share (Chetty, 1999). Thus, the analysis of international strategy should also include decisions about the extension of the geographical scope of operations (Welch \& Luostarinen, 1988). According to the process approach, internationalisation follows an incremental pattern from geo-culturally close to more distant 
markets (Andersen, 1993, Johanson \& Vahlne, 2009;). Thereby, companies can allocate their resources over a limited number of markets or follow a strategy of market diversification. However, the strategy of diversification can lead to a decrease of the number of markets in the long run, as a result of re-concentration and exit from less profitable markets in the international portfolio. A fast rate of expansion can result in a limited managerial attention, thus exposing entrants to mistakes in the market choice and resulting in subsequent de-internationalisation (Ayal \& Zif,1979; Bamberger \& Upitz, 2007).

Furthermore, while the operating modes within one foreign market and for one given product unit might remain constant, the extent of value added by a foreign venture can vary. A wholly-owned subsidiary can carry out different activities along the value chain. Moreover, in a particular country, different entry modes can be used by a company to handle different parts of the value chain (Benito, Petersen \& Welch, 2009). Changes in foreign governance of value adding activities can be seen from a global strategy perspective, depending on decisions concerning an international concentration or dispersion of activities (Porter, 1986). This can result from critical success factors of the company's industry, ranging between the need for global integration of value activities and the increase of operating efficiency, and the need for local responsiveness and adaptation to the local market environment (Prahalad \& Doz, 1987).

Finally, the rising complexity of international activities requires firms to integrate differentiated parts of the entire system. The strength of integration of international involvements into the corporate network can express itself in the interdependence of resources and responsibilities between the units of a multinational corporation. According to this view, the network of customers, competitors, suppliers and other actors in international markets plays a crucial role in achieving the firm's long-term goals (Johanson \& Mattson, 1988). Chetty (1999) regard internationalisation as a process driven by the creation of relationships with network partners in new foreign markets, through increasing commitment to extant foreign networks and through integrating positions in networks in different foreign markets.

Clearly, one should note that there are important interrelationships between the said dimensions of internationalisation, which have recently been discussed in international management and international entrepreneurship literature. The strategic-thinking approach emphasises the links between a firm's strategic orientation and its internationalisation patterns, processes and pace. Bell, Crick and Young (2004) found important differences between the internationalisation processes of knowledge-intensive and traditional manufacturing SMEs, the latter being involved in foreign markets from the very beginning of their operations, relying on foreign networks to a larger extent, entering a larger number of export markets with new global offerings (Hagen, Zuchchello, Cerchiello \& de Giovanni, 2012).

One must note that the dimensions of the internationalisation strategy of the firm have mostly been discussed in isolation from each other, with few attempts at linking them holistically and exploring their combinations which may form certain strategic profiles or archetypes. Cerrato, Crosato and Depperu (2016) propose that the degree of internationalisation of a firm also includes an attitudinal component, which is represented by top management's international orientation. In fact, top management's experiential, motivational, and attitudinal resources deeply affect the internationalisation process of a firm (Escriba-Esteve, Sanchez-Peinado, \& Sanchez-Peinado, 2008). Specifically, international 
orientation positively correlates with the extent of top management's international experience, as management's overseas experience plays a role in affecting a firm's predisposition to future international activities (Zucchella, Palamara, \& Denicolai, 2007).

Further, the internationalisation of a firm's business network is another key dimension, as this dimension affects the range of opportunities a firm can access and the resources and competencies it can leverage in its international activities. The inclusion of this component reflects the shift from a traditional view that looks at internationalisation essentially in terms of the amount of a firm's resources and assets allocated abroad to a perspective emphasising the importance of a firm's network for its foreign activities (Bjorkman \& Forsgren, 2000). According to the network approach to internationalisation, relationships primarily drive international business opportunities and decisions, thus enabling firms to leverage critical external resources (Chetty, 1999). In particular, networking plays a highly important role for small firms, as they may exploit networks to mitigate the limitations due to their size or limited experience. Finally, the internationalisation of firms takes place not only in the area of production, but also involves a financial dimension based on the type of investors that firms consider (Hassel, Hopner, Kurdelbusch, Rehder, \& Zugeho, 2003). Internationalisation should therefore be evaluated also as to how a company internationalises its financing or ownership structure.

To sum up the above discussion, the internationalisation of a firm implies changes along several dimensions. Thus, defining a firm's international footprint merely in terms of its international sales or the number of foreign direct investments would therefore present a simplified image. For instance, not only the number, but also the geographic-cultural distance of countries should be considered, as more distant markets are argued to increase the firm's internationalisation degree (Kutschker, 2002). Moreover, the presence in a given foreign market will differ in terms of the realised value chain modules, such as purchasing, $R \& D$, manufacturing, logistics and sales. It has been suggested that the extent and diversity of foreign added value activities also determine the internationalisation degree (Kutschker, 1994). It was further underlined that - since an increased internationalisation requires an enhanced integration of the whole company - a higher mutual interdependence and intensity of resource flows between subsidiaries, as well as a higher unification of shared values, norms and beliefs imply a higher degree of firm internationalisation (Kutschker, 2002).

One can argue that depending on the development stage of a company, emphasis will shift between the above discussed dimensions. Therefore, following the classification of Ringlstetter and Skrobarczyk (1994), three successive maturity stages of firm internationalisation can be distinguished, starting from the internationalisation of the product-market strategy, through the internationalisation of value activities, to the most advanced stage of internationalisation of the organisation, in which more or less autonomous parts of the international network need to be integrated into the corporation.

\section{Firm internationalisation and business models}

While there have been several attempts to analyse internationalisation strategy in its different dimensions (as outlined above), the concept of business models was applied to firm internationalisation less often. Hennart (2014) argues that it is the business model of the firm that can drive and explain international expansion. Specifically, he attempted to show that the business model used by the so called international new ventures and born globals, namely the product they sell, how they sell it, and to whom, is pivotal in explaining why 
they sell quickly to customers in many countries. This explicit consideration of different aspects of the business model in firm internationalisation is rare, although the relevance of industry-specific factors has long been acknowledged.

In this context, Rask (2014) links firm internationalisation to the stream of business model innovation (BMI). He recalls that the business model answers the "what" question (products on offer), the "how" question (How to create value related to the product) and the "who" question (related to customers and their needs, and the suppliers assisting in the value creation process). Since business model innovation is not about product innovation, the two basic how and who questions remain valid. At this juncture one can note that, in line with the discussion in the preceding sections, there are conceptual overlaps in the dimensions of internationalisation strategy and business model. For instance, Hagen and Zucchella (2014) point to the relevance of a business idea and strategy on the basis of which a company identifies and exploits a market opportunity, organises its value chain, selects areas to be internationalised, and defines unique ways to reach potential customers. Extant research indicates that rapid internationalisation is frequently related to the realisation of a niche strategy, which implies introducing specialised products, innovative marketing strategies and enhanced product and service quality (Mudambi \& Zahra, 2007).

We argue that in the context of firm internationalisation, the presence of apparent overlaps in the dimensions of internationalisation strategy raised in extant literature, as well as the dimensions of business models, shifts analytical attention from a mechanic comparison of the two concepts to a more profound analysis of their relationships and the role which business models play for firm internationalisation. In fact, in line with the multidimensional process of firm internationalisation, the coordination of firm-specific assets must be managed across several countries by means of a possible variety of relevant business modes. In the ensuing sections we discuss several predominant perspectives in existing literature on business models and internationalisation.

As discussed earlier, the distinguishing characteristic of a business model is the way in which the type of product or service is linked to a particular group of customers using a specific communication and delivery method. Bouncken, Muench and Kraus (2015) argue that the distinctive characteristic of firms realising foreign sales from the very outset may pertain to differences in their business models per se, as well as their ability to adapt them to foreign markets. In contrast to other common internationalisation theories, the business model approach focuses on the holistic view of the firm's core activities in which business model innovation plays a pivotal role to gain competitive advantages.

Another group of scholars shifts attention from specific dimensions and their facilitating effects on international expansion to overall business models of internationalising firms, which have different implications for the shape of international operations. Onetti et al. (2012) and Bouncken et al. (2015) propose that business models of internationalising firms can be essentially discussed along the dimension of focus (which activities to perform), locus (where to allocate how much of these activities), and modus (to what extent these activities are performed alone or in cooperation, how much technology- or capital-intensive they are, etc.). Based on such categorisation, Rask (2014) proposes several types of business models with regard to the role of internationalisation of downstream (e.g. sales) and upstream (e.g. production) activities. Domestic-based business models are used by domestic ventures only. Even though the firm acts in a domestic context, its products and services 
can be sold internationally through other firms such as export houses and similar indirect sales channels. Firms with an import-based business model seek sales opportunities in the domestic market and rely on the global supply market, which, for example, is often the case for domestic supermarket chains. The export-based business model is the inverse of the import-based business model. Export firms concentrate their resources locally, exporting their goods to international markets where they can earn a higher profit than by selling them on the domestic market. Like importers, exporters' demand and supply-market knowledge offers them competitive advantages through their ability to spot and act on emerging opportunities. The export-based business model is the business model that most of the export marketing literature focuses on. Finally, the semi-global business model features the characteristics of both the import and the export-based business models.

While there have been efforts to explore the links between business models and firm internationalisation, less attention has been paid to the effects of business model choices on international performance. Among the very few attempts in this regard, Kraus, Brem, Schuessler, Schuessler and Niemand (2017) show that business model design matters to international firm performance and the business model design of born global companies tends to be more efficiency-centered. Having an efficiency-centered business model design is positively associated with the born global's international performance. However, more research in this regard is warranted, in particular with relation to the performance effects of different aspects of business models of internationalising firms.

\section{CONCLUSIONS}

Among extant research, Hennart's (2014) call for considering the nature of the business model in explaining accelerated internationalisation processes was one of the most important ones, raising a recent debate and a series of empirical studies reviewed here. Indeed, going beyond the popular variables analysed by IB scholars is pivotal to explaining not only the pace of international expansion, but also - if not in particular - its modes and loci. In this discussion paper we have departed from overall concepts of strategy and business models and reflected upon their commonalities and mutual relationships. We have then transferred this discussion to the level of firm internationalisation in order to review the usage of both concepts with regard to the international expansion decisions. Our review indicates that some of the dimensions of both concepts, including the operating modes, choice of products or markets, are common to both concepts. However, internationalisation appears to be an integral part of corporate-level strategy which defines the directions of long-term firm development, including the geographic dimension. Thus, considering different geographic commitments as partly independent, albeit interdependent, one can assume that while the entire firm has a business model as a whole, there can also be varieties of business models within the same organisation, which are a consequence of its growth, particularly internationalisation. These business models enable the implementation of the overall internationalisation strategy in different markets. Therefore, the concept of business model in the context of firm internationalisation has to be explored at several layers. This fact leads to several observations with regard to existing research and the implications for further research efforts. 
Firstly, among the reviewed studies there have been a number of papers devoted to how the business models can facilitate internationalisation. While the consideration of specific operational aspects behind firm internationalisation can indeed enrich our repertoire of variables and enhance our understanding of firm decisions, leading to more insightful findings, the bulk of attention has been paid to rapid internationalisation processes, including born globals or international new ventures. There have been no studies exploring the links between the overall business model and the internationalisation patterns of firms following more traditional approaches to internationalisation, as well as firms of different size and age than merely fast internationalising, smaller and younger firms.

Further, as it has been noted in our paper, some authors stress that firms can maintain several business models as they growth, which results from their rising sectoral and spatial complexity. This aspect can be an interesting enhancement to the predominant focus on overall business models of internationalising firms, as it raises questions as to the motivations to replicate or modify the core business model in new international contexts. Moreover, it can be also fruitful to study the extent to which the co-existence of different business models within the organisation can contribute to changes in the main business model, or whether and how it does affect business model design upon new market entries, i.e. whether and how the new business model can effectively draw from previous implementation experiences for companies opting for a co-evolutionary approach and - in contrast - for the ones which focus on replicating their business model due a variety of factors. Thus, the context of international expansion and the complexity which it carries can be useful for enriching general research on business model co-existence and co-evolution.

Finally, internationalisation research can also contribute to the stream on business model innovation, as the internationalisation of a firm's operations can be regarded as an organisational innovation in itself. A business model innovation requires a firm to timely and effectively identify and anticipate relevant developments in its constantly changing environment. The initiative to innovate an established business model has been identified as highly challenging due to its complexity and a range of barriers, particularly widespread inertia. The understanding of how internationalisation can inspire changes in the business model can be a promising step in this regard.

\section{REFERENCES}

Afuah, A. \& Tucci, C.L. (2003). Internet Business Models and Strategies. New York: McGraw-Hill/Irwin and the Environment.

Andersen, O. (1993). On the internationalization process of firms. A critical analysis. Journal of International Business Studies, 24(2), 209-231.

Ayal, I.\& Zif, J. (1979). Market Expansion Strategies in Multinational Marketing, Journal of Marketing, 43(1), 84-94.

Bamberger, I.\& Upitz, A. (2007). De-Internationalisierung. Working Paper 18, Fachgebiet Organisation \& Planung, University of Essen.

Bell, J., Crick, D. \& Young, S. (2004). Small Firm Internationalization and Business Strategy: An Exploratory Study of Knowledge-Intensive' and 'Traditional' Manufacturing Firms in the UK. International Small Business Journal, 22(1), 23-56.

Benito, G. R. G., Petersen, B. \& Welch, L. S. (2009). Towards more realistic conceptualisations of foreign operation modes, Journal of International Business Studies, 40(9), 1455-1470. 
Benito, G. R. G. \& Welch, L. S. (1994). Foreign market servicing: beyond choice of entry mode. Journal of International Marketing, 2 (2), 7-27.

Bjorkman, I., \& Forsgren, M. (2000). Nordic international business research. International Studies of Management and Organization, 30(1), 6-25.

Bouncken, R. B., Muench, M., \& Kraus, S. (2015). Born globals: Investigating the influence of their business models on rapid internationalization. The International Business \& Economics Research Journal (Online), 14(2), 247.

Calof, J. C. \& Beamish, P.W. (1995). Adapting to foreign markets. Explaining internationalization. International Business Review, 4(2), 115-131.

Cerrato, D., Crosato, L., \& Depperu, D. (2016). Archetypes of SME internationalization: A configurational approach. International Business Review, 25(1), 286-295.

Chetty, S. (1999). Dimensions of internationalisation of manufacturing firms in the apparel industry, European Journal of Marketing, 33 (1/2), 121-142.

Doligalski T. (2014). Modele biznesu w Internecie. Teoria i studia przypadków polskich firm. Warszawa: Wydawnictwo Naukowe PWN.

Escriba-Esteve, A., Sanchez-Peinado, L. \& Sanchez-Peinado, E. (2008). Moderating influences on the firm's strategic orientation-performance relationship. International Small Business Journal, 26(4), 463-489.

Fletcher, R. (2001). A holistic approach to internationalisation. International Business Review, 10 (1), 25-49.

Gołębiowski T., Dudzik T.M., Lewandowska M., \& Witek-Hajduk M. (2008). Modele biznesu polskich przedsiębiorstw, Warszawa: Szkoła Główna Handlowa

Gorynia, M. (2007). Strategie zagranicznej ekspansji przedsiębiorstw. Warszawa: Polskie Wydawnictwo Ekonomiczne.

Hagen, B., \& Zucchella, A. (2014). Born global or born to run? The long-term growth of born global firms. Management International Review, 54(4), 497-525.

Hagen, B., Zucchella, A., Cerchiello, P. \& De Giovanni, N. (2012). International strategy and performance-Clustering strategic types of SMEs. International Business Review, 21 (3), 369-382.

Hassel, A., Ho“pner, M., Kurdelbusch, A., Rehder, B., \& Zugeho“ ret, R. (2003). Two dimensions of the internationalization of firms. Journal of Management Studies, 40(3), 705-723.

Hennart, J. F. (2014). The accidental internationalists: a theory of born globals. Entrepreneurship Theory and Practice, 38(1), 117-135.

Hitt, M. A., Ireland, R. D. \& Hoskisson, R. E. (1999). Strategic management: Competitiveness and globalization : concepts and cases. Cincinnati, Ohio: South-Western College Pub.

Johanson, J. \& Mattsson, L.G. (1988). Internationalization in Industrial Systems-A Network Approach. In Hood, N. \& Vahlne, J.(Eds.), Strategies in Global Competition (pp. 11-23). New York: Croom Helm.

Johanson, J., Vahlne, J. E. (2009). The Uppsala internationalization process model revisited: From liability of foreignness to liability of outsidership. Journal of International Business Studies, 40 (9), 1411-1431.

Kraus, S., Brem, A., Schuessler, M., Schuessler, F. \& Niemand, T. (2017). Innovative born globals: Investigating the influence of their business models on international performance. International Journal of Innovation Management, 21, 1-44.

Kutschker, M., (1994). Strategische Kooperation als Mittel der Internationalisierung. In Schuster, L. (Ed.), Die Unternehmung im internationalen Wettbewerb (pp. 121-157) Berlin: Schmidt. 
Kutschker, M. (2002). Internationalisierung der Unternehmensentwicklung. In Macharzina, K. \& Oesterle, M.J. (Eds.), Handbuch Internationales Management. Grundlagen - Instrumente Perspektiven, 2 (pp. 46-67). Wiesbaden: Gabler.

Magretta J. (2003). What Management is? London: Profile Books.

Magretta, J. (2002). Why Business Models Matter. Harvard Business Review, 80(5), 86-92.

Mintzberg, H., Ahlstrand, B. W., \& Lampel, J. (1998). Strategy safari: A guided tour through the wilds of strategic management. New York: Free Press.

Mudambi, R., \& Zahra, S. (2007). The survival of international new ventures. Journal of International Business Studies, 38(2), 333-352.

Obłój K. (2002). Tworzywo skutecznych strategii. Na styku starych i nowych reguł konkurencji, Warszawa: PWE.

Onetti, A., Zucchella, A., Jones, M. V., \& McDougall-Covin, P. P. (2012). Internationalization, innovation and entrepreneurship: business models for new technology-based firms. Journal of Management \& Governance, 16(3), 337-368.

Osterwalder, A. \& Pigneur, Y. (2010). Business Model Generation. Hoboken: Wiley \& Sons.

Porter, M. E. (1980). Competitive strategy: Techniques for analyzing industries and competitors. New York: Free Press.

Porter, M. E., (1986). Changing Patterns of International Competition. California Management Review, 28(2), 9-40.

Porter, M.E. (2001). Strategy and the Internet. Harvard Business Review, 79 (3), 62-78.

Prahalad, C. K. \& Doz, Y. L. (1987). The Multinational Mission: Balancing Local Demands and Global Vision. New York: Free Press.

Rask, M. (2014). Internationalization through business model innovation: In search of relevant design dimensions and elements. Journal of International Entrepreneurship, 12(2), 146-161.

Ringlstetter, M. \& Skrobarczyk, P. (1994). Die Entwicklung internationaler Strategien, Zeitschrift für Betriebswirtschaft 64, 333-357.

Stähler, P. (2002). Geschäftsmodelle in der digitalen Ökonomie. Merkmale, Strategien und Auswirkungen. Lohmar: Eul Verlag.

Timmers, P. (1998). Business Models for Electronic Markets. Journal on Electronic Markets, 8 (2), 3-8.

Verbeke, A., Li, L. \& Goerzen, A. (2009). Toward More Effective Research on the MultinationalityPerformance Relationship. Management International Review, 49, 149-162.

Welch, L. S. \& Luostarinen, R. (1988). Internationalization. Evolution of a concept. Journal of General Management, 14(2), 34-55.

Zucchella, A., Palamara, G., \& Denicolai, S. (2007). The drivers of the early internationalization of the firm. Journal of World Business, 42(3), 268-280. 


\section{Authors}

The contribution of co-authors is equal and can be expressed as $33 \%$ each of the authors.

\section{Marian Gorynia}

Full Professor at Poznań University of Economics and Business (Poland). His research interests include foreign direct investment, firm internationalisation, industral economics, economic policy. Correspondence to: Prof. Marian Gorynia, PhD, Department of International Competitiveness Poznań University of Economics and Business al. Niepodległości 10, 61-875 Poznań, Poland, email: m.gorynia@ue.poznan.pl

ORCID (ib) http://orcid.org/0000-0002-7633-8249

\section{Piotr Trąpczyński}

Associate Professor at Poznań University of Economics and Business (Poland). His research interests include firm internationalisation, international strategies, international entrepreneurship.

Correspondence to: Prof. Piotr Trąpczyński, PhD, Department of International Competitiveness Poznań University of Economics and Business, al. Niepodległości 10, 61-875 Poznań, Poland, email: piotr.trapczynski@ue.poznan.pl

ORCID (1) http://orcid.org/0000-0001-8154-9174

\section{Szymon Bytniewski}

PhD Student at Poznań University of Economics and Business (Poland). His research interests include internationalization, business models, international competitiveness, international business, globalization.

Correspondence to: Mr. Szymon Bytniewski, International Competitiveness Department, Poznań University of Economics and Business, al. Niepodległości 10, 61-875 Poznań, Poland, e-mail: szymon.bytniewski@ue.poznan.pl

ORCID (i) http://orcid.org/0000-0002-4095-3741

\section{Copyright and License}

This article is published under the terms of the Creative Commons

Attribution - NoDerivs (CC BY-ND 4.0) License

http://creativecommons.org/licenses/by-nd/4.0/

Published by the Centre for Strategic and International Entrepreneurship - Krakow, Poland

The journal is co-financed in the years 2019-2020 by the Ministry of Science and Higher Education of the Republic of Poland in the framework of ministerial programme "Support for Scientific Journals" (WCN) on the basis of contract no. 238/WCN/2019/1 concluded on 15 August 2019. 
